\title{
Species diversity and drivers of arbuscular mycorrhizal fungal communities in a semi-arid mountain, China
}

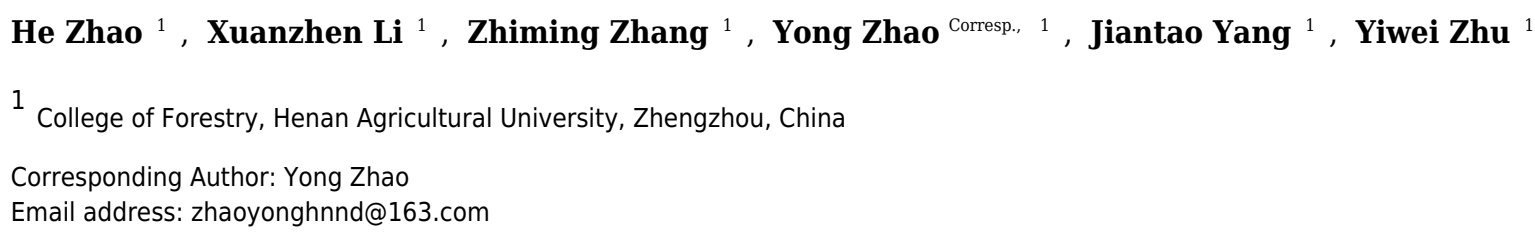

Arbuscular mycorrhizal fungi (AMF) played an essential role in complex ecosystems. However, the species diversity and composition of AMF community remain unclear in semiarid mountain. Further, it is not well understood if the characteristics of AMF community assembly differs for different habitat types, e.g., agricultural arable land, artificial forest land, natural grassland, and bush/wood land. Here, using the high-throughput technology by Illumina sequencing on MiSeq platform, we explored the species diversity and composition of soil AMF communities among different habitat types in a semi-arid mountain (Taihang Mountain, Mid-western region of China). Then we analyzed the effect of nutrient composition and soil texture on AMF community assembly. Our results showed that members of the Glomus genera were predominated in all soil types. The distancebased redundancy analysis indicated that the content of water, available phosphorus, and available potassium were the most crucial geochemical factors that significantly affected AMF communities $(p<0.05)$. The analysis of the soil texture confirmed that AMF diversity was negatively correlated with soil clay content. The comparison of AMF diversity among the various habitat types revealed that the artificial forest land had the lowest AMF diversity in comparison with other land types. Our findings suggest that there were differences in species diversity and composition of soil AMF communities among different habitat types. These findings shed new light on the characteristics of community structure and drivers of community assembly in AMF in semi-arid mountains, and point to the potential importance of different habitat types on AMF communities. 


\section{China}

$3 \mathrm{He} \mathrm{Zhao}^{1 \dagger}$, Xuanzhen $\mathrm{Li}^{1 \dagger}$, Zhiming Zhang ${ }^{1}$, Yong Zhao ${ }^{1 *}$, Jiantao Yang ${ }^{1}$ and Yiwei Zhu ${ }^{1}$

4 1. College of Forestry, Henan Agricultural University, Zhengzhou, China

5 *Correspondence: zhaoyonghnnd@163.com

6 These authors have contributed equally to this work. 
8 ABSTRACT: Arbuscular mycorrhizal fungi (AMF) played an essential role in complex ecosystems. However,

9 the species diversity and composition of AMF community remain unclear in semi-arid mountain. Further, it is

10 not well understood if the characteristics of AMF community assembly differs for different habitat types, e.g.,

11 agricultural arable land, artificial forest land, natural grassland, and bush/wood land. Here, using the high-

12 throughput technology by Illumina sequencing on MiSeq platform, we explored the species diversity and

13 composition of soil AMF communities among different habitat types in a semi-arid mountain (Taihang

14 Mountain, Mid-western region of China). Then we analyzed the effect of nutrient composition and soil texture

15 on AMF community assembly. Our results showed that members of the Glomus genera were predominated in

16 all soil types. The distance-based redundancy analysis indicated that the content of water, available phosphorus,

17 and available potassium were the most crucial geochemical factors that significantly affected AMF

18 communities $(\mathrm{p}<0.05)$. The analysis of the soil texture confirmed that AMF diversity was negatively

19 correlated with soil clay content. The comparison of AMF diversity among the various habitat types revealed

20 that the artificial forest land had the lowest AMF diversity in comparison with other land types. Our findings

21 suggest that there were differences in species diversity and composition of soil AMF communities among

22 different habitat types. These findings shed new light on the characteristics of community structure and drivers

23 of community assembly in AMF in semi-arid mountains, and point to the potential importance of different

habitat types on AMF communities. 


\section{INTRODUCTION}

Arbuscular mycorrhizal fungi (AMF) play high value for ecosystem restoration and sustainability (Herder et al., 2010; Sanders, 2010; Verbruggen et al., 2010). The majority of land plant species has the potential ability to form symbiotic relationships with AMF, which can significantly enhance plant growth (Lekberg \& Koide, 2005), improve soil structure (Piotrowski et al., 2004; Caravaca et al., 2006; Wilson et al., 2009), and contribute to plant resistance to environmental stress (Benjamina, Karl \& Johnn, 2009; Balliu, Sallaku \& Rewald, 2015). And AMF also can maintain ecosystems stability and promote ecosystem development (Larsen, Williams \& Kremen, 2005; Fuhrman, 2009; Rosindell, Hubbell \& Etienne, 2011). Therefore, to explore the ecological environment in diverse regions, understanding the AMF diversity and biogeography will be of primary importance (Fitter, 2005; Chaudhry et al., 2012).

In recent years, lots of studies have reported the AMF community composition in different environmental condition (Öpik et al., 2006; Wubet et al., 2006; Heijden \& Scheublin, 2007; Lee, Lee \& Young, 2008; Krüger et al., 2009). Scholars have argued that the composition of AMF communities will vary along the gradients of land-use intensity under the same climatic conditions and region of agricultural ecosystems (Dumbrell et al., 2010; Fritz et al., 2010; Lekberg et al., 2011; Mirás-Avalos et al. 2011, Meadow \& Zabinski , 2012). And several papers also confirmed that the AMF distributions are caused by their ability to tolerate high nutrient concentrations in different habitat types (Porras-Alfaro et al., 2007; Egertonwarburton, Johnson \& Allen, 2008; Thomson, Robson \& Abbott, 2010). Meanwhile, through the investigation of natural or agricultural habitats, scholars have shown that a high diversity of rhizosphere AMF was found in natural habitat (Öpik et al., 2008; Bonfim et al., 2016), and the AMF communities inhabiting plant roots tended to have a lower diversity in agricultural ecosystems (Daniell et al., 2001; Alguacil et al. 2011, Schnoor et al. 2011, Bainard et al., 2012). However, most of the previous research works focused on single ecosystems (Helgason et al., 1998; Lumini et al., 2010; Verbruggen \& Toby, 2012), and there are no comparative analyses on the AMF condition among different soil types under the same climate conditions in semi-arid regions.

Hitherto, traditional studies of AMF community composition have been scarce, partly due to the limitations of spore morphological features, which are easily influenced by external disturbances (Oehl et al., 2004), such as integrity of the spores (e.g., ability to identify spores). Due to the above defects, new research technologies are constantly updated. For instance, the development of molecular methods has greatly facilitated the studies of AMF taxonomic and phylogenetic reconstruction and has enhanced the sensitivity of AMF identification and quantification (Lekberg et al., 2007; Helgason \& Fitter, 2009; Balestrini et al. 2010, Gast et al., 2011). Moreover, significant improvements have been made in the analysis of AMF condition by the high-throughput technology (Margulies et al., 2006). Determining the diversity of AMF became very widespread by using regions of the small ribosomal subunit gene. Due to technology advancements, it can provide the most comprehensive reference sequence data set (Öpik et al., 2010), and the sequencing data can provide detailed analyses on AMF communities among complex habitat types (Öpik et al., 2013). In summary, the application of new technologies will greatly improve the study of AMF communities. 
Thus, our study applied the high-throughput sequencing (Illumina platform) to analyze the soil AMF communities in four habitat types, including agricultural arable land, artificial forest land, natural grassland, and bush/wood land, and in contrast to the first two soil habitat types, the last two types were undisturbed (without human interference). All habitat types were located in the Taihang Mountain, which belongs to the semi-arid ecosystem. We aimed to identify the relative importance of soil characteristics on AMF diversity and illustrate the differences in AMF communities among the predominant soil types. The research would be a valuable contribution toward a better understanding on the way human activities have changed the composition of the current AMF communities, and the results would contribute to developeing a more precise guidance on local soil reclamation, vegetation restoration, and the maintenance of biodiversity in semi-arid regions.

\section{MATERIALS AND METHODS}

\section{Study Area}

The research site was located in the south of Taihang Mountain $\left(112^{\circ} 28^{\prime}-112^{\circ} 30^{\prime} \mathrm{E}, 35^{\circ} 01^{\prime}-35^{\circ} 03^{\prime} \mathrm{N}\right)$, a site which belongs to the semi-arid area of China. The climate in the test area is temperate continental monsoon, with an annual average temperature of $14.3{ }^{\circ} \mathrm{C}$ and an average annual sunshine rate of $54 \%$; the elevation gradient of our study sites ranged from 231 to $432 \mathrm{~m}$ above sea level. Soil in the study area is cinnamon (main part is similar to ustalf USDA), and the parent rock was composed mainly of sandstone and shale. The habitat types in this study were bush/wood land, forest land, grassland, and arable land. The bush/wood land included mainly Vitex negundo L, Lespedeza bicolor Turcz and Ziziphus jujuba Mill. var. spinosa (Bunge) Hu ex H. F. Chow, Forest land included mainly Quercus variabilis B1., Platycladus orientalis (L.) Franco, and Robinia pseudoacacia L. Dominant herbaceous plants in the grassland were Setaria viridis (L.) Beauv., Artemisia princeps H. Lév. and Vaniot, Pennisetum alopecuroides (L. ) Spreng., Arthraxon hispidus (Thunb.) Makino, and Rehmannia glutinosa (Gaetn.) Libosch. ex Fisch. et Mey. Finally, the prevalent herbaceous plants in the arable land were Zea mays L., Triticum aestivum L., Ipomoea batatas L., Brassica campestris L., and Lycopersicon esculentum Mill.

\section{Sample collection}

In October 2016, soil samples were collected in triplicate at four sites (W1, BW, WL, and F). The sample collection occurred at the root zone of the plant at a soil depth of 5-10 cm (Table 1). Site W1 represented the forest land soil type; site BW had bush/wood soil type; site WL was characterized by grassland soil type; and arable land soil type was represented in site F. These 12 soil samples collected were placed in sterile plastic bags and transported in freezing boxes to the laboratory, and they were stored at $-70{ }^{\circ} \mathrm{C}$ until further analysis.

\section{Soil Geochemical Analyses}

We analyzed eight different soil factors, including soil $\mathrm{pH}$, water content, available nitrogen $\left(\mathrm{NH}^{+}{ }_{4}-\mathrm{N}\right)$, available potassium $\left(\mathrm{K}^{+}-\mathrm{K}\right)$ and phosphate phosphorus $\left(\mathrm{PO}^{3-}{ }_{4}-\mathrm{P}\right)$. Soil $\mathrm{pH}$ was examined by a $\mathrm{pH}$ meter ( $\mathrm{PX}-$ 
95

96

KS06, Guangzhou Puxi Instrument, Guangzhou, China). Water content was measured by drying soil method, and the content of soil clay, silt, and sand was performed by using a Malvern Mastersizer (Mastersizer2000, Malvern Instruments, Malvern, UK). The available nitrogen and available potassium were analyzed by an Autoanalyzer (SEAL-AA3, SEAL Analytical, Milwaukee, WI, USA); phosphate phosphorus analyzed by $\mathrm{NaHCO}_{3} \mathrm{Mo}-\mathrm{Sb}$ colorimetric method.

\section{Molecular analyses DNA extraction}

$50 \mathrm{mg}$ soil was used for metagenomic DNA extraction in each sample, using the Fast DNA Isolation Kit (Q-BIOgene, Heidelberg, Germany). The extracts were stored at $-20{ }^{\circ} \mathrm{C}$ for PCR. $1.0 \%$ agarose gels for checking DNA concentration and purity.

\section{Miseq sequencing step}

Using the 18S rRNA gene and primer sets of AMV4.5N Forward 5'-AAGCTCGTAGTTGAATTTCG-3' and AMDG R 5'-CCCAACTATCCCTATTAATCAT-3' to amplify the sequences (from soil DNA extracts), the primer had been reported to be acceptable in several previous studies (Sato et al., 2005). The initial PCR reactions were similar to the existing studies of Xiao, including :25 $\mu \mathrm{L}$ total volumes, 1-2 $\mu \mathrm{L}$ DNA template, $250 \mathrm{mM}$ dNTPs, $0.25 \mathrm{mM}$ of primer, $1 \mathrm{X}$ reaction buffer and 0.5U Phusion DNA Polymerase (Xiao et al., 2005).

The reactions used a 2720 model Thermal Cycler, and initial PCR amplification was conducted under the steps below: $94{ }^{\circ} \mathrm{C}$ for 2 -min, then 25 cycles of 30 -s denaturation at $94{ }^{\circ} \mathrm{C}, 30$-s annealing at $56{ }^{\circ} \mathrm{C}, 30$-s extension at $72{ }^{\circ} \mathrm{C}, 5$-min extension at $72{ }^{\circ} \mathrm{C}$. The second step PCR used a template, which come from the first $5 \mathrm{uL}$ product (without dilution). The second step PCR include: one cycle of 3-min at $94{ }^{\circ} \mathrm{C}$, then 8 cycles of 30 s at $94{ }^{\circ} \mathrm{C}, 56{ }^{\circ} \mathrm{C}$ for 30 -s and $72{ }^{\circ} \mathrm{C}$ for 30 -s, and a 5 -min extension at $72{ }^{\circ} \mathrm{C}$. The PCR products were separated by electrophoresis (1.5\% agarose gel in $0.5 \times \mathrm{TBE})$ and purified using a gel xxtraction kit (Axygen Biosciences, Corning, NY, USA), then the libraries were sequenced by PE300 sequencing on MiSeq v3 Reagent Kit (Illumina) platform (at Tiny Gene Company, Shanghai).

\section{Bioinformatics methods}

The sequence reads were analyzed by the combination of software Mothur v. 1.33.3, UPARSE (usearch version v8.1.1756) and R 3.2.2, the original FASTQ files were demultiplexed through the barcode (Schloss et al., 2009). The PE reads for all samples were merged based on mothur. The low quality contigs were removed based on screen.seqs command by the settings filter ( $\operatorname{maxambig}=0$, minlength $=200$, maxlength $=580$, the higher threshold can protect some longer sequences, which may be the correct fragment, maxhomop $=8$ ). The decoded data information was aggregated (97\% homology) to operational taxonomic units (OTUs) (Edgar, 2013).

BLAST analysis was conducted using the "Nucleotide collection $(\mathrm{nr} / \mathrm{nt})$ " database. No threshold was 
128

set for E values, alignment length and identity settings. For each OTU representative sequence, a list of top BLAST hits was compiled. Uncultured clones were deleted from the list of top hits. The BLAST get the highest score was identifed as the match's species.

\section{Statistical Analyses}

For the alpha-diversity analysis, Mothur v. 1.33.3 software was used to analyze the OTU richness, Coverage, Chao, and Shannon's indices as reported earlier by Schloss et al (2009) (Schloss et al., 2009). The values of soil properties and diversity parameters were statistically analysed by SPSS V. 19 software (one-way ANOVA ).

The clustering method was used with R v. 3.1.1 software to identify the AMF relationship (based on OTU abundance-based). Further, the indicator species analysis was utilized to identify the AMF communities associated with various habitat types (Dufrene \& Legendre P, 1997).

Using the Canoco software (Canoco for Windows 4.5 package) (Braak \& Smilauer, 2002), we utilized Monte Carlo permutation and distance-based redundancy (db-RDA) tests to explain the correlation between soil AMF and geochemical factors. In addition, the heatmap results of the abundance percentages of AMF genera were obtained by Mothur v. 1.33.3 software. The raw sequence information has been deposited into the NCBI database (Accession No. SRP116770).

\section{RESULTS}

\section{Soil Properties}

For the eight geochemical factors measured, the arable land obtained the maximum values of water content, available phosphorus and available potassium (site F). Meanwhile the minimum values of water content and available phosphorus were established in the grassland (site WL). In the bush/wood land (site BW), the maximum values of sand content (average 28.9\%), but minimum silt content (35.5\%) were established (Table 1).

\section{AMF Diversity Data and Community Composition}

In the current study, we have identified a total of 532,841 sequences and 803 OTUs from the total dataset, there were 320,899 sequences belonged to phylum Glomeromycotina (accounting for $60.2 \%$ ). The number of sequences in each of the samples ranged from 15,095 to 35,206, and the number of AMF OTUs ranged from 52 to 83 (genetic distances of 3\%). The OTUs' coverage in all soil types reached 99\% (Table 2). On the basis of the OTU richness calculated by Chao's index, the grassland observed the greatest AMF value (site WL: 81). Through the analysis of Shannon's index, we discovered that the largest AMF diversity was also present in the grassland (site WL: 3.49-3.52 with an average value of 3.51), followed by the arable land (site F: 3.38-3.46 with an average value of 3.43), bush/wood land (site BW: 3.38-3.46 with average 3.42), and the forest land soils (site W1: 2.53-3.15 with an average value of 2.87) (Table 2). 
161

162

163

164

165

166

167

168

Some variations in AMF community composition at the genus level were also detected among all soil samples. The 119 OTUs that could be classified were affiliated with ten AMF genera, whereas those that could not be identified were assigned as unclassified. The Glomus were the most abundant genera in all samples: $60 \%-75 \%$ in grassland, $70 \%-75 \%$ in arable land, $75 \%-80 \%$ in bush/wood, and $50 \%-70 \%$ in forest land. Meanwhile, their levels varied in the different soil types. Ambispora were found in all samples, but a greater abundance was detected in the grassland and arable land samples than in those of the bush/wood and forest land soils (Figure 1).

\section{Correlation among the three factors (AMF Communities, Soil Types and Environmental condition)}

To determine the differences in soil AMF community, the OTU cluster analysis showed that the 12 soil samples were divided into four Soil Types (Figure 2), and the indicator species analysis revealed that there were $60 \mathrm{AMF}$ indicators (indicator value $>0.25, \mathrm{p}<0.05$ ) in this 4 groups types, it mainly included bush/wood (Glomus and Diversispora taxa), arable land (Glomus, Septoglomus and Rhizophagus taxa), grassland (Glomus and Septoglomus taxa), forest land (Glomus and Paraglomus taxa) (Table S1).

The top 50 OTUs of all samples were selected and their abundances were compared by heatmap software. It revealed the relative distributions and abundances of the top 50 OTUs in all samples (Figure 3). More detailed information about the top 50 OTUs was presented in Table S2. And there was a listing of all AMF OTUs and their closest matches in Table S3.

The distance-based redundancy analysis (db-RDA) showed that there was a significant correlation between the combination of eight environmental factors and soil AMF community structure, that $81.9 \%$ of the soil community variation was attributed to all environmental factors (Figure 4 and Table 3). However, using the Monte Carlo permutation test, we found that water content $\left(\mathrm{r}^{2}=0.7332, \mathrm{p}<0.01\right)$, available phosphorus $\left(\mathrm{r}^{2}\right.$ $=0.7576, \mathrm{p}<0.01)$, available potassium $\left(\mathrm{r}^{2}=0.7973, \mathrm{p}<0.01\right)$, silt $\left(\mathrm{r}^{2}=0.6461, \mathrm{p}<0.05\right)$, and sand $\left(\mathrm{r}^{2}=\right.$ $0.6293, \mathrm{p}<0.05$ ) were important properties (Table 3).

\section{DISCUSSION}

As mentioned earlier, the study area was located in the South Taihang Mountains of China, whose climate characterizes the region as a typical semi-arid climate zone. Under natural conditions, the thin soil layer, low forest coverage and much gravel are the characteristics of this area. Its forest types are mainly dominated by human intervention of Quercus variabilis Bl and Platycladus orientalis (L.); the vegetation is poor and only limited species could be planted (Zhao, 2007). Thus, improving local soil conditions and promoting plant growth are urgent tasks. However, some information had remained unexplored for the Taihang Mountain area, such as the distribution of AMF communities, the variation of AMF diversity, and the influence of various soil types on AMF composition. Therefore, in this study, we investigated the AMF communities among the predominant soil types in the South Taihang Mountain region. The results could be a valuable reference for improving the local ecological environment.

By analyzing the results of the 4 different soil types, the research showed that the diversity of AMF 
196

197

198

199

200

201

202

203

204

205

206

207

208

209

210

211

212

213

214

215

216

217

218

219

220

221

222

223

224

225

226

227

228

229

230

231

communities in undisturbed grassland soil type was greater than that in artificial forest land (Table 2). That was consistent with Öpik et al. (2008), whose discovered that rich biological species composition and low external disturbance may lead to higher diversity of rhizosphere AMF of the natural vegetation soil. Our results showed that the value of Shannon's index in arable land was larger than that in artificial forest land. This outcome might have been caused by the cultivation practices implemented by the farmers, including the application of farmyard manure (food residues, livestock manure, etc.), which increased the number of microbial communities by raising the level of available nutrients (Helgason \& Fitter, 2009). Indeed, it is generally accepted that the organic agriculture farming methods are regarded as a useful measure to increase AMF diversity (Aroca, Porcel \& Ruizlozano, 2007), and farmers in that region usually apply farmyard manure with cultivation methods that are closed to organic agriculture farming. On the other hand, probably because the growth and reproduction of specific AMF communities requiring particular host plant species, it leads to a less abundant community under a single artificial plantation habitat (Long et al., 2010). In general, human disturbance caused changes in the forest land environment, which reduced the transportation and distribution of AMF communities (Yuan et al., 2008), and the artificial forest land had the lowest AMF diversity in comparison with other land types.

Meanwhile, the results of the sequence data analysis of AMF community composition showed that members of both genera Septoglomus and Glomus existed in different soil types, including forest land, bush/wood, grassland, and arable land. Nevertheless, the representatives of Glomus were identified to be the main genus, and although Glomus, Diversispora, Septoglomus, Rhizophagus and Paraglomus were found in soils, only Glomus taxa served as indicator species for each habitat. These results are similar to previously published research that confirmed that the species of Glomus were the most abundant in the AMF assemblage (Oehl et al., 2005). The influence of certain factors may be the reason why Glomus was the dominant members in the AMF assemblage among those of other genera. Some researchers revealed that the species of Glomus genus can usually produce large numbers of spores and hypha fragments, which can colonize and extensively spread onto the roots of plants (Öpik et al., 2006). Glomus has also a certain resistance in complex environments (Miransari et al., 2008; Bever et al., 2009; Barto et al., 2011). Therefore, these features facilitate the survival and spread of Glomus genus members in a semi-arid mountain, and the emergence of this phenomenon is also the result of adaptation to the local ecological environment.

Moreover, our investigation established that water content is a significant factor which has an obvious effect on the AMF communities. Scholars have shown that the variations in the water content can contribute to changes in the physiological status of local AMF and its ecological niche directly (Sieverding, Toro \& Mosquera, 1989), the reason was probably due to the water was essential for the reproductive and metabolic processes. Thus, the water content can indirectly exert an impact on the distribution of AMF communities. In addition, our research also confirmed that there are significant relationships between the available phosphorus, available potassium, and soil AMF community structure. These interactions were most likely attributable to the fact that soil phosphorus may stimulate the spore germination and hyphal growth of AMF (Miranda \& Harris, 
232

233

234

235

236

237

238

239

240

241

242

243

1994), and the potassium has the ability to increase the infection rate of AMF under drought stress (Wei, 2016). In general, soil nutrients can have on the growth of local AMF communities as the lack of nutrients inhibits the production and separation of spores (Zaller, Frank \& Drapela, 2011). Thus, this work confirmed that environmental factors can drive the composition and distribution of AMF communities.

Furthermore, the composition of AMF communities seems to have been strongly influenced by the soil texture distribution, and our results showed that the content of silt and sand were significantly related to the soil AMF community (Table 1). The AMF diversity was higher in the samples from low-clay but high-sand content soil types. The appearance of the result was probably due to the fact that AMF is an aerobic organism, and the lower clay content provided better aeration, which was advantageous for plant root growth and soil humus decomposition, leading also to accelerated fungal propagation (Torrecillas et al., 2014). The research confirmed that AMF communities was negatively correlated with soil clay content.

\section{CONCLUSIONS}

In conclusion, this study first delineated the species diversity and composition of AMF community in Taihang Moutain, China. The members of the Glomus genus were predominant in all soil types. The findings also suggested that nutrient composition and soil texture were the most important factors affecting AMF community. Moreover, there were differences in species diversity and composition of soil AMF communities among different habitat types. These findings shed new light on the characteristics of community structure and drivers of community assembly in AMF in semi-arid mountains, and point to the potential importance of different habitat types on AMF communities.

\section{ACKNOWLEDGEMENTS}

The authors are grateful to the staff of the Xiaolangdi Ecological Station in Henan Province, China, for the provision of the soil materials and testing ground. We also would like to thank the Tiny Gene Bio-Tech (Shanghai) Co., Ltd. for their high-throughput sequence technology.

\section{REFERENCES}

Alguacil MM, Torrecillas E, Caravaca F, Fernández DA, Azcón R, and Roldán A. 2011. The application of an organic amendment modifies the arbuscular mycorrhizal fungal communities colonizing native seedlings grown in a heavy-metal-polluted soil. Soil Biology \& Biochemistry 43:1498-1508.

Aroca R, Porcel R, and Ruizlozano JM. 2007. How does arbuscular mycorrhizal symbiosis regulate root hydraulic properties and plasma membrane aquaporins in Phaseolus vulgaris under drought, cold or salinity stresses? New Phytologist 173:808-816.

Bainard LD, Dai M, Gomez EF, Torres-Arias Y, Bainard JD, Sheng M, Eilers W, and Hamel C. 2015. Arbuscular mycorrhizal fungal communities are influenced by agricultural land use and not soil type among the Chernozem great groups of the Canadian Prairies. Plant and Soil 387:351-362.

Balestrini R, Magurno F, Walker C, Lumini E, and Bianciotto V. 2010. Cohorts of arbuscular mycorrhizal fungi (AMF) in Vitis vinifera, a typical Mediterranean fruit crop. Environmental Microbiology Reports 2:594604.

Balliu A, Sallaku G, and Rewald B. 2015. AMF Inoculation Enhances Growth and Improves the Nutrient Uptake 
Rates of Transplanted, Salt-Stressed Tomato Seedlings. Sustainability 7:15967-15981.

Barto EK, Hilker M, Müller F, Mohney BK, Weidenhamer JD, and Rillig MC. 2011. The Fungal Fast Lane: Common Mycorrhizal Networks Extend Bioactive Zones of Allelochemicals in Soils. Plos One 6:e27195.

Benjamina S, Karl C, and Johnn K. 2009. Plant and fungal identity determines pathogen protection of plant roots by arbuscular mycorrhizas. Journal of Ecology 97:1274-1280.

Bever JD, Richardson SC, Lawrence BM, Holmes J, and Watson M. 2009. Preferential allocation to beneficial symbiont with spatial structure maintains mycorrhizal mutualism. Ecology Letters 12:13-21.

Bonfim JA, Vasconcellos RL, Gumiere T, De LCMD, Oehl F, and Nogueira Cardoso EJ. 2016. Diversity of Arbuscular Mycorrhizal Fungi in a Brazilian Atlantic Forest Toposequence. Microbial Ecology 71:164.

Braak CJFT, and Smilauer P. 2002. CANOCO Reference Manual and CanoDraw for Windows User's Guide: Software for Canonical Community Ordination (version 4.5). Ithaca Ny Usa Www.

Caravaca F, Alguacil MM, Azcon R, and Roldan A. 2006. Formation of stable aggregates in rhizosphere soil of Juniperus oxycedrus: Effect of AM fungi and organic amendments. Applied Soil Ecology 33:30-38.

Chaudhry V, Rehman A, Mishra A, Chauhan PS, and Nautiyal CS. 2012. Changes in Bacterial Community Structure of Agricultural Land Due to Long-Term Organic and Chemical Amendments. Microbial Ecology 64:450-460.

Daniell TJ, Husband R, Fitter AH, and Young JPW. 2001. Molecular diversity of arbuscular mycorrhizal fungi colonising arable crops. Fems Microbiology Ecology 36:203-209.

Dufrene M, and Legendre P. 1997. Species Assemblages and Indicator Species: The Need for a Flexible Asymmetrical Approach. Ecological Monographs 67:345-366.

Dumbrell AJ, Nelson M, Helgason T, Dytham C, and Fitter AH. 2010. Idiosyncrasy and overdominance in the structure of natural communities of arbuscular mycorrhizal fungi: is there a role for stochastic processes? Journal of Ecology 98:419-428.

Edgar RC. 2013. UPARSE: highly accurate OTU sequences from microbial amplicon reads. Nature Methods 10:996.

Egertonwarburton LM, Johnson NC, and Allen EB. 2008. Mycorrhizal community dynamics following nitrogen fertilization: A cross-site test in five grasslands. Ecological Monographs 77:527-544.

Fitter AH. 2005. Presidential Address: Darkness Visible: Reflections on Underground Ecology. Journal of Ecology 93:231-243.

Fritz O, Endre L, Arno B, Karl S, Robert B, Marcelvander H, and Ewald S. 2010. Soil type and land use intensity determine the composition of arbuscular mycorrhizal fungal communities. Soil Biology \& Biochemistry 42:724-738.

Fuhrman JA. 2009. Fuhrman JA.. Microbial community structure and its functional implications. Nature 459: 193199. Nature 459: 193 .

Gast CJVD, Gosling P, Tiwari B, and Bending GD. 2011. Spatial scaling of arbuscular mycorrhizal fungal diversity is affected by farming practice. Environmental Microbiology 13:241-249.

Heijden MGAVD, and Scheublin TR. 2007. Functional traits in mycorrhizal ecology: their use for predicting the impact of arbuscular mycorrhizal fungal communities on plant growth and ecosystem functioning. New Phytologist 174:244-250.

Helgason T, Daniell TJ, Husband R, Fitter AH, and Young JPW. 1998. Ploughing up the wood-wide web? Nature 394:431. Nature 394:431. 
310

311

312

313

314

315

316

317

318

319

320

321

322

323

324

325

326

327

328

329

330

331

332

333

334

335

336

337

338

339

340

341

342

343

344

345

346

347

348

349

350

Helgason T, and Fitter AH. 2009. Natural selection and the evolutionary ecology of the arbuscular mycorrhizal fungi (Phylum Glomeromycota). Journal of Experimental Botany 60:2465.

Herder GD, Isterdael GV, Beeckman T, and Smet ID. 2010. The roots of a new green revolution. Trends Plant Sci. Trends in Plant Science 15:600-607.

Krüger M, Stockinger H, Krüger C, and Schüßler A. 2009. DNA-based species level detection of Glomeromycota: one PCR primer set for all arbuscular mycorrhizal fungi. New Phytologist 183:212-223.

Larsen TH, Williams NM, and Kremen C. 2005. Extinction order and altered community structure rapidly disrupt ecosystem functioning. Ecology Letters 8:538-547.

Lee J, Lee S, and Young JPW. 2008. Improved PCR primers for the detection and identification of arbuscular mycorrhizal fungi. Fems Microbiology Ecology 65:339-349.

Lekberg Y, and Koide RT. 2005. Is plant performance limited by abundance of arbuscular mycorrhizal fungi? A meta-analysis of studies published between 1988 and 2003. 168:189-204.

Lekberg Y, Koide RT, Rohr JR, Aldrich-Wolfe L, and Morton JB. 2007. Role of Niche Restrictions and Dispersal in the Composition of Arbuscular Mycorrhizal Fungal Communities. Journal of Ecology 95:95105.

Lekberg Y, Meadow J, Rohr JR, Redecker D, and Zabinski CA. 2011. Importance of dispersal and thermal environment for mycorrhizal communities: lessons from Yellowstone National Park. Ecology 92:12921302.

Long LK, Yao Q, Guo J, Yang RH, Huang YH, and Zhu HH. 2010. Molecular community analysis of arbuscular mycorrhizal fungi associated with five selected plant species from heavy metal polluted soils. European Journal of Soil Biology 46:288-294.

Lumini E, Orgiazzi A, Borriello R, Bonfante P, Bianciotto V, Bonfante P, Visick K, and Ohkuma M. 2010. Disclosing arbuscular mycorrhizal fungal biodiversity in soil through a land-use gradient using a pyrosequencing approach. Environmental Microbiology 12:2165-2179.

Margulies M, Egholm M, Altman WE, Attiya S, Bader JS, Bemben LA, Berka J, Braverman MS, Chen YJ, and Chen Z. 2006. Genome sequencing in microfabricated high-density picolitre reactors. Nature 437:376-380.

Meadow JF, and Zabinski CA. 2012. Linking symbiont community structures in a model arbuscular mycorrhizal system. New Phytologist 194:800-809.

Mirás-Avalos JM, Antunes PM, Koch A, Khosla K, Klironomos JN, and Dunfield KE. 2011. The influence of tillage on the structure of rhizosphere and root-associated arbuscular mycorrhizal fungal communities. Pedobiologia 54:235-241.

Miranda JCCD, and Harris PJ. 1994. Effects of soil phosphorus on spore germination and hyphal growth of arbuscular mycorrhizal fungi. New Phytologist 128:103-108.

Miransari M, Bahrami HA, Rejali F, and Malakouti MJ. 2008. Using arbuscular mycorrhiza to alleviate the stress of soil compaction on wheat ( Triticum aestivum L.) growth. Soil Biology \& Biochemistry 40:11971206.

Oehl F, Sieverding E, Ineichen K, Ris EA, Boller T, and Wiemken A. 2005. Community structure of arbuscular mycorrhizal fungi at different soil depths in extensively and intensively managed agroecosystems. New Phytologist 165:273-283.

Oehl F, Sieverding E, Mäder P, Dubois D, Ineichen K, Boller T, and Wiemken A. 2004. Impact of long-term 
conventional and organic farming on the diversity of arbuscular mycorrhizal fungi. Oecologia 138:574-583.

ÖPIK M, Moora M, Liira J, and Zobel M. 2006. Composition of root-colonizing arbuscular mycorrhizal fungal communities in different ecosystems around the globe. Journal of Ecology 94:778-790.

Opik M, Moora M, Zobel M, Saks U, Wheatley R, Wright F, and Daniell T. 2008. High diversity of arbuscular mycorrhizal fungi in a boreal herb-rich coniferous forest. New Phytologist 179:867-876.

Opik M, Vanatoa A, Vanatoa E, Moora M, Davison J, Kalwij JM, Reier U, and Zobel M. 2010. The online database MaarjAM reveals global and ecosystemic distribution patterns in arbuscular mycorrhizal fungi (Glomeromycota). New Phytologist 188:223.

Öpik M, Zobel M, Cantero JJ, Davison J, Facelli JM, Hiiesalu I, Jairus T, Kalwij JM, Koorem K, and Leal ME. 2013. Global sampling of plant roots expands the described molecular diversity of arbuscular mycorrhizal fungi. Mycorrhiza 23:411-430.

Piotrowski JS, Denich T, Klironomos JN, Graham JM, and Rillig MC. 2004. The effects of arbuscular mycorrhizas on soil aggregation depend on the interaction between plant and fungal species. New Phytologist 164:365-373.

Porras-Alfaro A, Herrera J, Natvig DO, and Sinsabaugh RL. 2007. Effect of long-term nitrogen fertilization on mycorrhizal fungi associated with a dominant grass in a semiarid grassland. Plant and Soil 296:65-75.

Rosindell J, Hubbell SP, and Etienne RS. 2011. The unified neutral theory of biodiversity and biogeography at age ten. Ecology 26:340-348.

Sanders IR. 2010. |[1squo]|Designer|[rsquo]| mycorrhizas|[quest]|: Using natural genetic variation in AM fungi to increase plant growth. Journal of Cultural Studies 3:1081-1083.

Sato K, Suyama Y, Saito M, and Sugawara K. 2005. A new primer for discrimination of arbuscular mycorrhizal fungi with polymerase chain reaction-denature gradient gel electrophoresis. Grassland Science 51:179-181.

Schloss PD, Westcott SL, Ryabin T, Hall JR, Hartmann M, Hollister EB, Lesniewski RA, Oakley BB, Parks DH, and Robinson CJ. 2009. Introducing mothur: open-source, platform-independent, communitysupported software for describing and comparing microbial communities. Appl Environ Microbiol 75:7537-7541.

Schnoor TK, Lekberg Y, Rosendahl S, and Olsson PA. 2011. Mechanical soil disturbance as a determinant of arbuscular mycorrhizal fungal communities in semi-natural grassland. Mycorrhiza 21:211-220.

Sieverding E, Toro S, and Mosquera O. 1989. Biomass production and nutrient concentrations in spores of va mycorrhizal fungi. Soil Biology \& Biochemistry 21:69-72.

Thomson BD, Robson AD, and Abbott LK. 2010. Effects of phosphorus on the formation of mycorrhizas by gigaspora calospora and glomus fasciculatum in relation to root carbohydrates. New Phytologist 103:751765 .

Torrecillas E, Alguacil MDM, Roldán A, Díaz G, Montesinosnavarro A, and Torres MP. 2014. Modularity Reveals the Tendency of Arbuscular Mycorrhizal Fungi To Interact Differently with Generalist and Specialist Plant Species in Gypsum Soils. Applied \& Environmental Microbiology 80:5455-5466.

Verbruggen E, and Toby KE. 2010. Evolutionary ecology of mycorrhizal functional diversity in agricultural systems. Evolutionary Applications 3:547-560.

Verbruggen E, Van DH, MARCEL G. A, Weedon JT, Kowalchuk GA, and Röling WFM. 2012. Community 
392

393

394

395

396

397

398

399

400

401

402

403

404

405

406

407

408

409

410

411

412 assembly, species richness and nestedness of arbuscular mycorrhizal fungi in agricultural soils. Molecular Ecology 21:2341.

Wei SZ. 2016. The interactive effects of arbuscular mycorrhizal fungus and postassium application on lycium barbarum L. responding to drought stress. Northwest A\&F University.(in Chinese)

Wilson GW, Rice CW, Rillig MC, Springer A, and Hartnett DC. 2009. Soil aggregation and carbon sequestration are tightly correlated with the abundance of arbuscular mycorrhizal fungi: results from longterm field experiments. Ecology Letters 12:452-461.

Wubet T, Weiß M, Kottke I, Teketay D, and Oberwinkler F. 2006. Phylogenetic analysis of nuclear small subunit rDNA sequences suggests that the endangered African Pencil Cedar, Juniperus procera, is associated with distinct members of Glomeraceae. Mycological Research 110:1059-1069.

Xiao E, Krumins V, Song T, Xiao T, Ning Z, Lan X, and Sun W. 2016. Correlating microbial community profiles with geochemical conditions in a watershed heavily contaminated by an antimony tailing pond Environmental Pollution 215:141-153.

Yuan YW, Vestberg M, Walker C, Hurme T, Zhang X, and Lindström K. 2008. Diversity and infectivity of arbuscular mycorrhizal fungi in agricultural soils of the Sichuan Province of mainland China. Mycorrhiza 18:59-68.

Zaller JG, Frank T, and Drapela T. 2011. Soil sand content can alter effects of different taxa of mycorrhizal fungi on plant biomass production of grassland species. European Journal of Soil Biology 47:175.

Zhao Y. 2007. Analysis and evaluation on degraded ecosystem ecological characterizes of vegetation restoration process in the hill areas of the Taihang Moutains. (Doctoral dissertation) Henan Agricultural University.(in Chinese) 


\section{$414 \quad$ Figures:}

415 Figure 1. Abundance percentages of AMF genera for all soil samples.

416 Figure 2. Clustering analysis of AMF communities based on OTU abundance for each soil.

417 Figure 3. Heat map of top 50 OTUs in all samples. The color intensity (log scale) in each panel shows the 418 percentage of a genus in a sample, referring to color key at the bottom.

419 Figure 4. Distance-based redundancy (db-RDA) tests used to interpret the correlations between the AMF 420 communities and environmental properties.

421 
422 Tables:

423 Table 1. Geochemical characteristics of the soil samples and other information of the site of the present

424 study.

425 Table 2 . The results of sequence data in the present study.

426 Table 3. Monte Carlo permutation tests were used to detect the relationship between community 427 composition and soil variables.

428 
Figure 1

Abundance percentages of AMF genera for all soil samples.

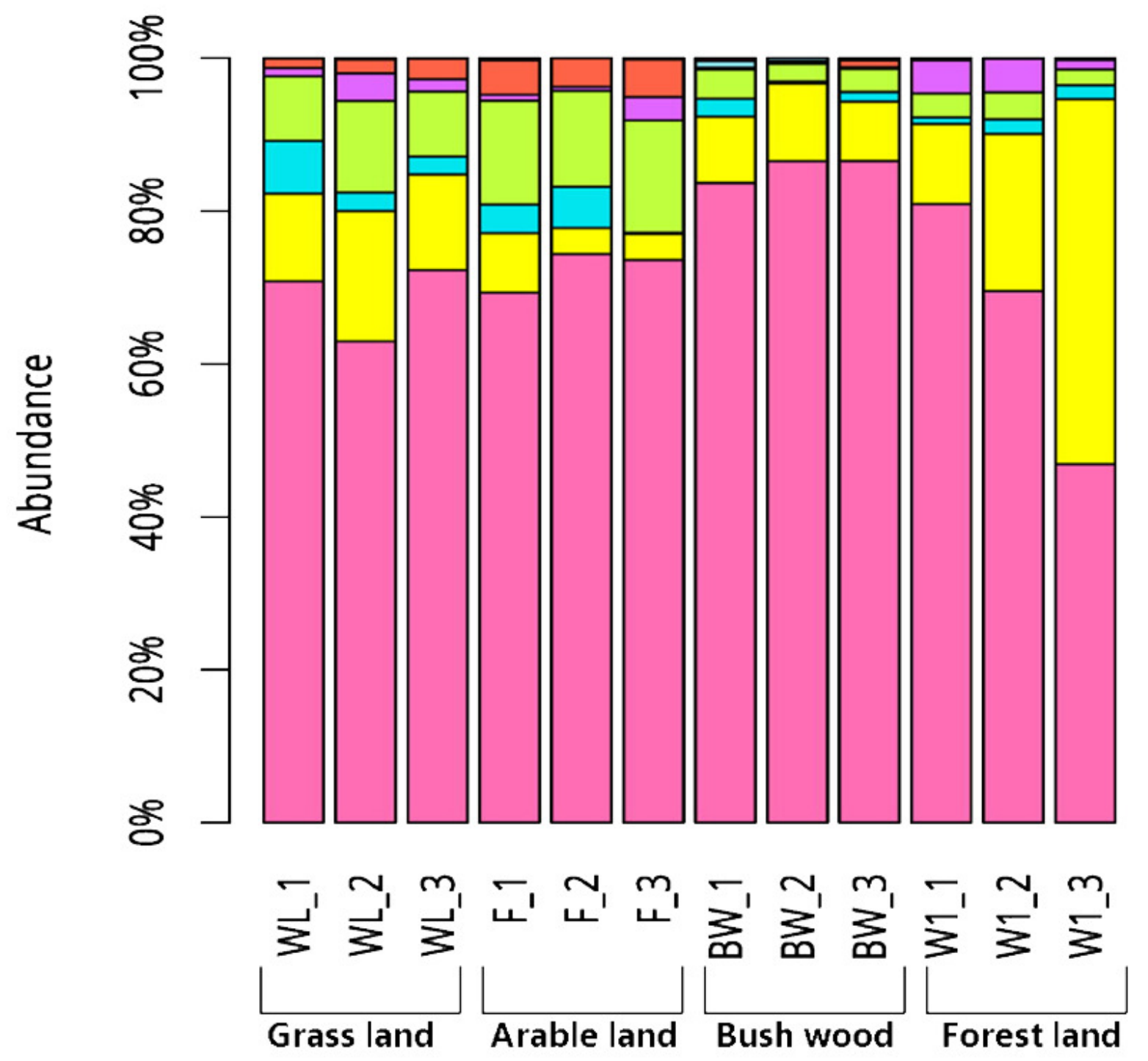

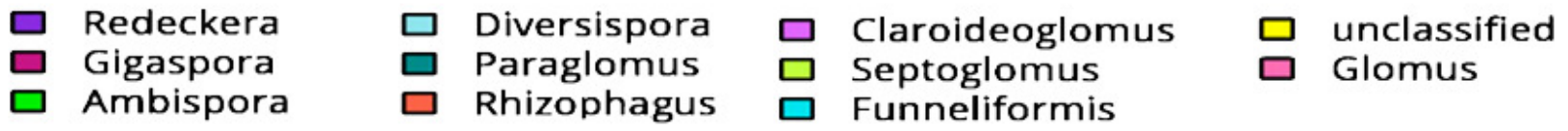


Figure 2

Clustering analysis of AMF communities based on OTU abundance for each soil. 


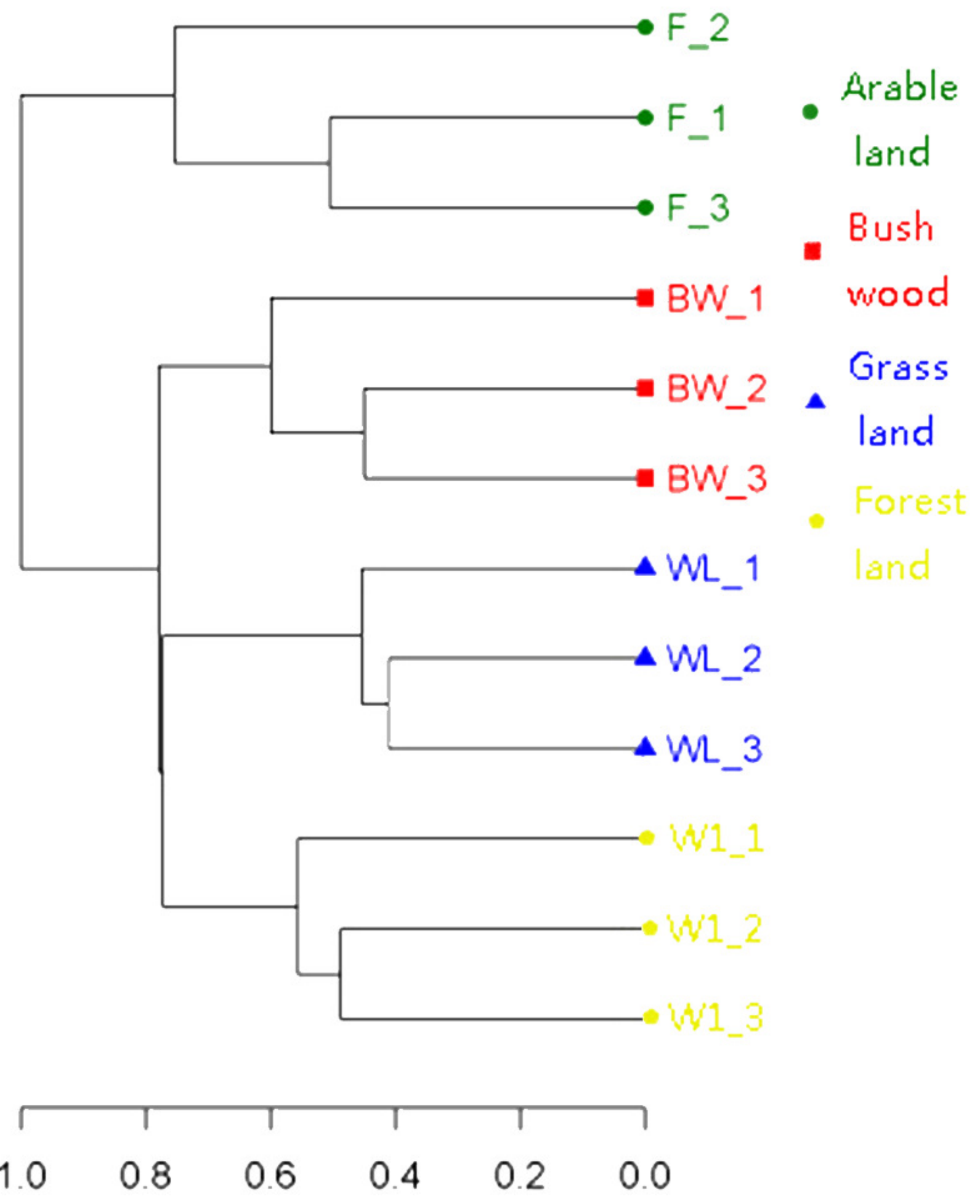


Figure 3

Heat map of top 50 OTUs in all samples.

The color intensity (log scale) in each panel shows the percentage of a genus in a sample, referring to color key at the bottom. 


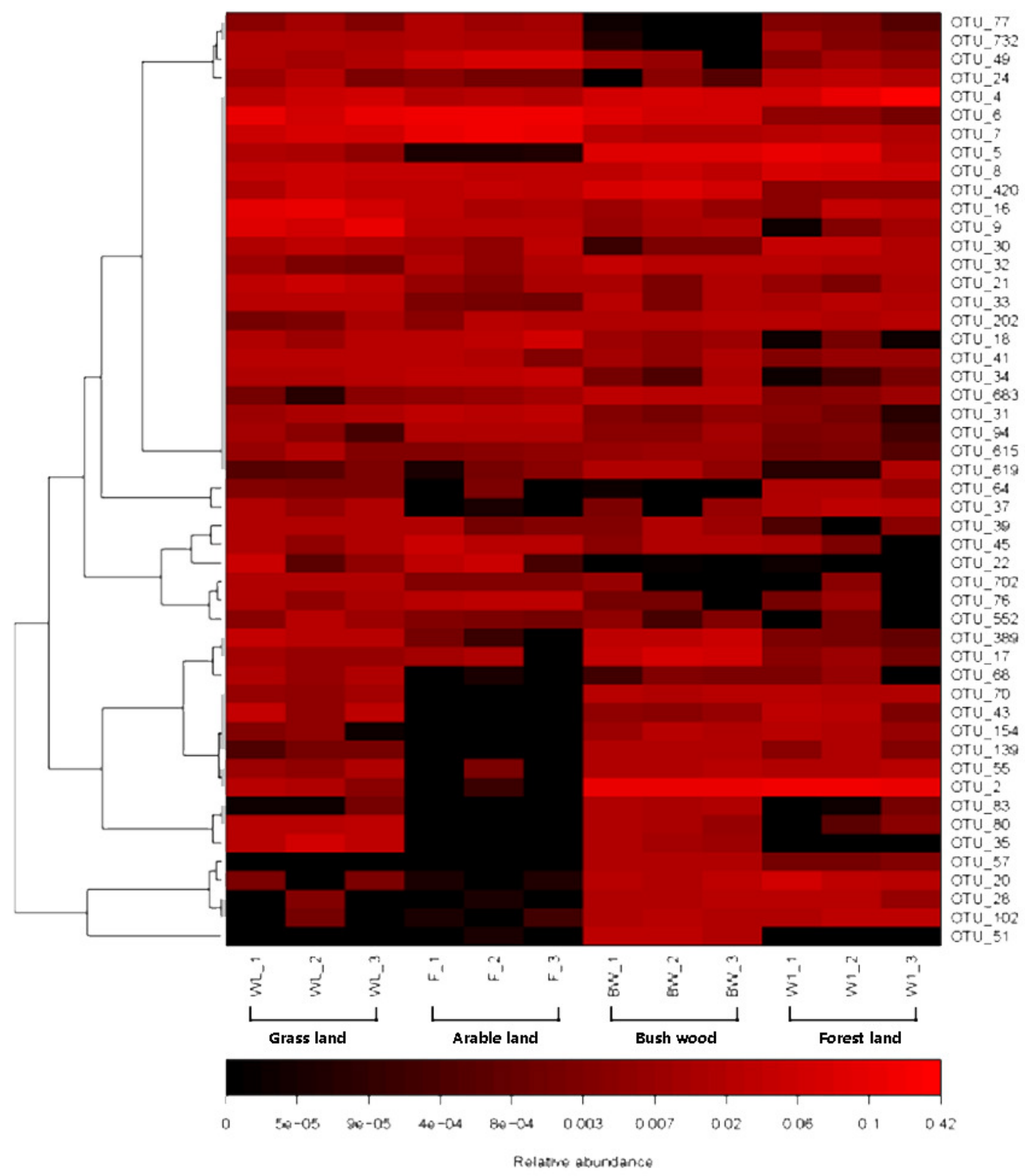


Figure 4

Distance-based redundancy ( $d b-R D A)$ tests used to interpret the correlations between the AMF communities and environmental properties.

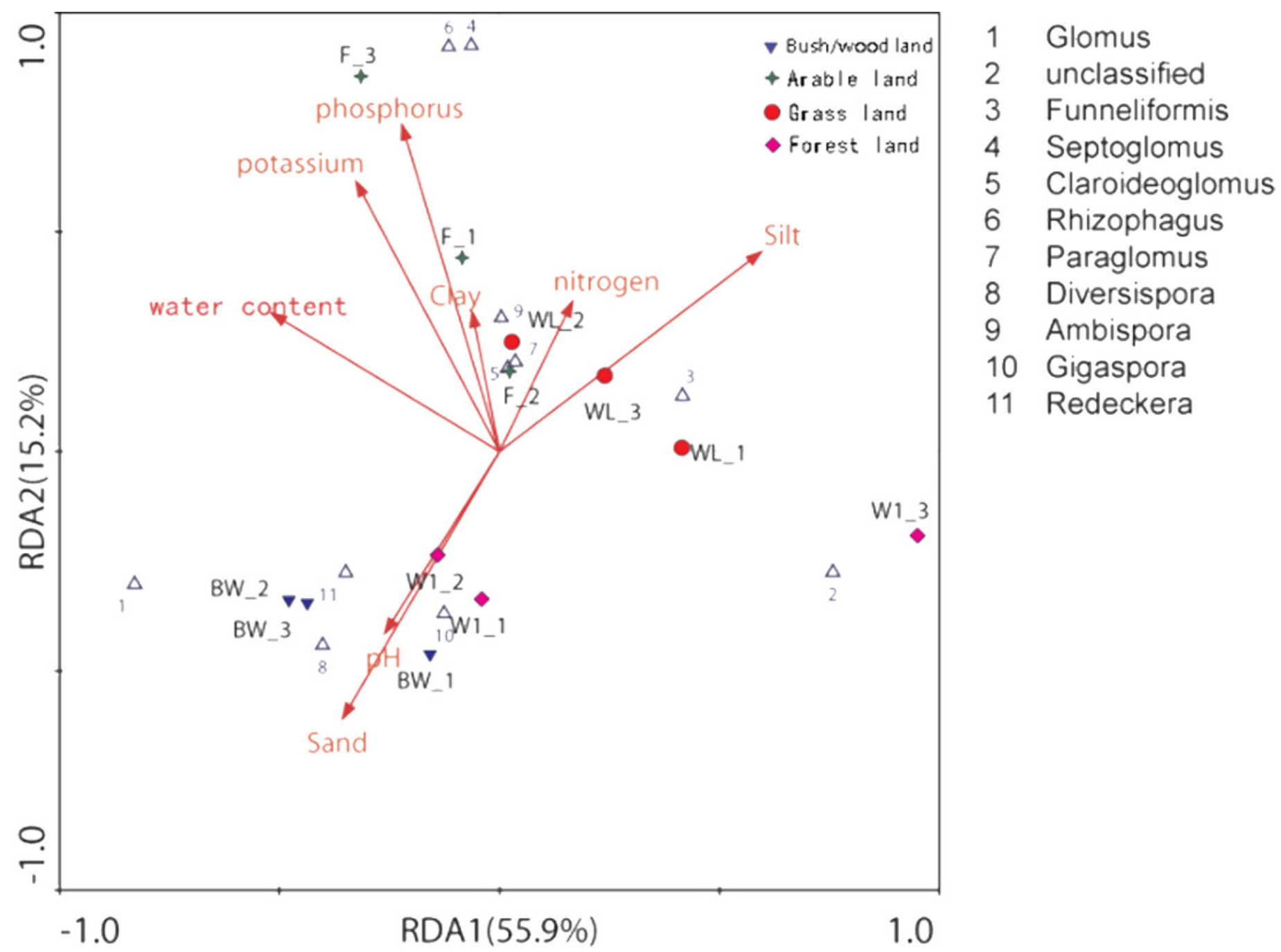




\section{Table $\mathbf{1}$ (on next page)}

Geochemical characteristics of the soil samples and other information of the site of the present study. 
Table 1. Geochemical characteristics of the soil samples and other information of the site of the present study.

\begin{tabular}{|c|c|c|c|c|c|c|c|c|c|c|}
\hline $\begin{array}{l}\text { Sample } \\
\text { sample }\end{array}$ & $\begin{array}{l}\text { Soil } \\
\text { type }\end{array}$ & Coordinates & $\mathrm{pH}$ & $\begin{array}{c}\text { Water } \\
\text { content }(\%)\end{array}$ & $\begin{array}{c}\text { Available } \\
\text { nitrogen } \\
\mathrm{mg} \cdot \mathrm{kg}^{-1} \mathrm{y}\end{array}$ & $\begin{array}{c}\text { Available } \\
\text { phosphorus } \\
\mathrm{mg} \cdot \mathrm{kg}^{-1} \mathrm{y}\end{array}$ & $\begin{array}{l}\text { Available } \\
\text { potassium } \\
\left(\mathrm{mg} \cdot \mathrm{kg}^{-1} \mathrm{y}\right.\end{array}$ & Clay(\%) & Silt(\%) & Sand $(\%)$ \\
\hline W1-1 & Forest & $35^{\circ} 1{ }^{\prime} 56^{\prime \prime} \mathrm{N} 112^{\circ} 29^{\prime} 1 " \mathrm{E}$ & 7.32 & 19.81 & 155.3 & 7.8 & 169.5 & 47.1 & 41.5 & 11.4 \\
\hline W1-2 & land & $35^{\circ} 2^{\prime} 16^{\prime \prime N} 112^{\circ} 28^{\prime} 20^{\prime \prime} \mathrm{E}$ & 7.41 & 20.24 & 145.3 & 6.9 & 143.4 & 46.2 & 44.5 & 9.3 \\
\hline W1-3 & & $35^{\circ} 2^{\prime} 45^{\prime \prime} \mathrm{N} 112^{\circ} 28^{\prime} 52^{\prime \prime} \mathrm{E}$ & 7.34 & 18.29 & 182.3 & 7.2 & 162.4 & 41.2 & 48.9 & 9.9 \\
\hline Average & & & $7.36 \mathrm{~A}$ & $19.44 \mathrm{~B}$ & $161.0 \mathrm{~A}$ & $7.3 \mathrm{~B}$ & $158.4 \mathrm{~B}$ & $44.9 \mathrm{AB}$ & $45.0 \mathrm{~A}$ & $10.2 \mathrm{C}$ \\
\hline BW-1 & Bush/ & $35^{\circ} 1^{\prime} 49^{\prime \prime} \mathrm{N} 112^{\circ} 29^{\prime} 14^{\prime \prime} \mathrm{E}$ & 7.53 & 20.33 & 141.5 & 4.7 & 177.4 & 37.3 & 32.1 & 30.6 \\
\hline BW-2 & wood & $35^{\circ} 2^{\prime} 3{ }^{\prime \prime N} 112^{\circ} 29^{\prime} 29^{\prime \prime E}$ & 7.41 & 21.14 & 133.2 & 4.8 & 186.4 & 41.2 & 31.5 & 27.3 \\
\hline BW-3 & & $35^{\circ} 2^{\prime} 55^{\prime \prime} \mathrm{N} 112^{\circ} 29^{\prime} 1 " \mathrm{E}$ & 7.36 & 23.00 & 187.3 & 6.5 & 160.1 & 28.3 & 42.9 & 28.8 \\
\hline Average & & & $7.43 \mathrm{~A}$ & $21.49 \mathrm{~B}$ & $154 \mathrm{~A}$ & $5.3 \mathrm{~B}$ & $174.6 \mathrm{~B}$ & $35.6 \mathrm{BC}$ & $35.5 \mathrm{~B}$ & $28.9 \mathrm{~A}$ \\
\hline WL-1 & Grass & $35^{\circ} 1^{\prime} 41^{\prime \prime} \mathrm{N} 112^{\circ} 29^{\prime} 39^{\prime \prime} \mathrm{E}$ & 7.21 & 16.71 & 167.4 & 4.3 & 129.1 & 33.2 & 52.6 & 14.2 \\
\hline WL-2 & land & $35^{\circ} 2^{\prime} 55^{\prime \prime} \mathrm{N} 112^{\circ} 29^{\prime} 12^{\prime \prime} \mathrm{E}$ & 7.34 & 15.90 & 144.3 & 5.1 & 135.4 & 26.4 & 49.6 & 24 \\
\hline WL-3 & & $35^{\circ} 1^{\prime} 38^{\prime \prime} \mathrm{N} 112^{\circ} 28^{\prime} 58^{\prime \prime} \mathrm{E}$ & 7.42 & 18.05 & 132.2 & 2.4 & 122.0 & 37.5 & 48.9 & 13.6 \\
\hline Average & & & $7.32 \mathrm{~A}$ & $16.88 \mathrm{C}$ & $148.0 \mathrm{~A}$ & $3.93 \mathrm{~B}$ & $128.8 \mathrm{C}$ & $32.37 \mathrm{C}$ & $50.4 \mathrm{~A}$ & $17.3 \mathrm{~B}$ \\
\hline F-1 & Arable & $35^{\circ} 2^{\prime} 31^{\prime \prime} \mathrm{N} 112^{\circ} 29^{\prime} 55^{\prime \prime E}$ & 7.27 & 26.71 & 177.5 & 18.7 & 287.4 & 55.2 & 39.5 & 5.3 \\
\hline $\mathrm{F}-2$ & land & $35^{\circ} 2^{\prime} 12^{\prime \prime} \mathrm{N} 112^{\circ} 29^{\prime} 38^{\prime \prime} \mathrm{E}$ & 7.45 & 23.71 & 183.5 & 22.5 & 254.3 & 50.1 & 43.6 & 6.3 \\
\hline F-3 & & $35^{\circ} 2^{\prime} 43^{\prime \prime} \mathrm{N} 112^{\circ} 29^{\prime} 19^{\prime \prime} \mathrm{E}$ & 7.33 & 23.95 & 182.3 & 30.2 & 299.1 & 47.8 & 47.5 & 4.7 \\
\hline Average & & & $7.35 \mathrm{~A}$ & $24.79 \mathrm{~A}$ & $181.1 \mathrm{~A}$ & $23.8 \mathrm{~A}$ & $280.3 \mathrm{~A}$ & $51.0 \mathrm{~A}$ & $43.53 \mathrm{AB}$ & $5.4 \mathrm{C}$ \\
\hline
\end{tabular}

Note: Values (eg. A,B,C) followed by the same letters in the same column was not significantly different $(\mathrm{p}<0.05)$. 
Table 2 (on next page)

The results of sequence data in the present study. 
Table 2. The results of sequence data in the present study.

\begin{tabular}{ccccccc}
\hline & $\begin{array}{c}\text { Soil } \\
\text { type }\end{array}$ & $\begin{array}{c}\text { Number of total } \\
\text { sequence }\end{array}$ & $\begin{array}{c}\text { Number of } \\
\text { AMF OTUs }\end{array}$ & Coverage (\%) & $\begin{array}{c}\text { Chao's } \\
\text { index }\end{array}$ & $\begin{array}{c}\text { Shannon's } \\
\text { index }\end{array}$ \\
\hline W1-1 & Forest & 26,866 & 62 & 99 & 67 & 2.93 \\
W1-2 & land & 27,298 & 71 & 99 & 73 & 3.15 \\
W1-3 & & 28,493 & 60 & 99 & 60 & 2.53 \\
Average & & & & & $67 \mathrm{~A}$ & $2.87 \mathrm{~B}$ \\
\cline { 3 - 7 } BW-1 & Bush/ & 31,391 & 73 & 99 & 74 & 3.46 \\
BW-2 & wood & 35,206 & 69 & 99 & 70 & 3.38 \\
BW-3 & & 32,153 & 67 & 99 & 68 & 3.42 \\
Average & & & & & $70 \mathrm{~A}$ & $3.42 \mathrm{~A}$ \\
WL-1 & Grass & 29,593 & 74 & 99 & 76 & 3.52 \\
WL-2 & land & 28,148 & 83 & 99 & 87 & 3.49 \\
WL-3 & & 28,621 & 76 & 99 & 79 & 3.51 \\
Average & & & & & $81 \mathrm{~A}$ & $3.51 \mathrm{~A}$ \\
\cline { 3 - 7 } F-1 & Arable & 18,900 & 52 & 99 & 67 & 3.46 \\
F-2 & land & 19,135 & 62 & 99 & 88 & 3.38 \\
F-3 & & 15,095 & 54 & 99 & 55 & 3.45 \\
Average & & & & & $70 \mathrm{~A}$ & $3.43 \mathrm{~A}$ \\
\hline
\end{tabular}

Note: The OTUs were defined at the cutoff $3 \%$ difference in sequence. Using the one-way analysis of variance (ANOVA) to evaluate statistical significance and results, followed by Tukey's HSD test. Capital direction symbols (eg. A,B,C) indicate full (5\%) significance. 


\section{Table 3 (on next page)}

Monte Carlo permutation tests were used to detect the relationship between community composition and soil variables 
1 Table 3. Monte Carlo permutation tests were used to detect the relationship between community composition 2 and soil variables.

\begin{tabular}{ccccc}
\hline & RDA1 & RDA2 & $\mathrm{r}^{2}$ & P-value \\
\hline $\mathrm{pH}$ & -0.2607 & -0.4144 & 0.2053 & 0.353 \\
Water content & -0.5188 & 0.3150 & 0.7332 & $0.004^{* *}$ \\
Available nitrogen & 0.1659 & 0.3414 & 0.3096 & 0.186 \\
Available phosphorus & -0.2218 & 0.7446 & 0.7576 & $0.004^{* *}$ \\
Available potassium & -0.3262 & 0.6153 & 0.7973 & $0.004^{* *}$ \\
Clay & -0.0622 & 0.3178 & 0.3611 & 0.156 \\
Silt & 0.5950 & 0.4549 & 0.6461 & $0.015^{*}$ \\
Sand & -0.3564 & -0.6083 & 0.6293 & $0.013^{*}$ \\
\hline
\end{tabular}

$3 *$ Correlation is significant at the 0.05 level.

$4 \quad * *$ Correlation is significant at the 0.01 level.

$5 \quad$ P-values based on 999 permutations.

6 